задачи невозможно формирование системного мышления и, следовательно, системного подхода к решению проблем, целеполагания. Именно эти качества необходимы каждому выпускнику вуза.

$$
* * *
$$

1. Богословский В.И., Бусыгина А.Л., Аниськин В.Н. Концептуальные основы высшего образования в условиях цифровой экономики // Самарский научный вестник, 2019. Т.8. №1 (26) [Электронный ресурс] Режим доступа: https://cyberleninka.ru/article/n/kontseptualnye-osnovy-vysshego-obrazovaniya-v-usloviyahtsifrovoy-ekonomiki/viewer, свободный.

2. Бурцева Э.В., Чепак О.А., Куликова О.А. Некоторые результаты исследования влияния цифровых технологий на учебную деятельность студентов // Педагогика и просвещение. - 2020. - № 1.

3. Варламова Л.Д. Проблемы межличностных отношений студентов технического вуза в условиях цифровизации общества // Мир науки. Педагогика и психология, 2019 №6, https://mirnauki.com/PDF/90PDMN619.pdf (доступ свободный).

4. Вербицкий А.А. Цифровое обучение: проблемы, риски и перспективы / А.А. Вербицкий // Электронный научно-публицистический журнал "Ноmo Cyberus". - 2019. - №1(6). [Электронный ресурс] - Режим доступа: http://journal.homocyberus.ru/Verbitskiy_AA_1_2019, свободный. - Загл. с экрана.

5. Вербицкий, А.А. «Цифровое поколение: проблемы образования»// Профессиональное образование. Столица. - № 7. - 2016. - С. 10-13.

6. Вербицкий А.А. Теория и технологии контекстного образования. Учебное пособие. - М., МПГУ, 2017.

7. Воинова О.И., Плешаков В.А. Личность и киберсоциум: становление киберсоциальности и классификация людей по степени интегрированности в киберсоциум // Электронный научно-публицистический журнал «Homo Cyberus». - $\quad 2018$. $\quad$ - $\quad$ № $1(4)$ [Электронный pecypc]URL: http://journal.homocyberus.ru/personality_and_cybersocium_formation_of_cybersafty_and_classification_of_people _according_to_the_extent_of_the_integration_into_the_cybersocium.

8. Выготский Л.С. Собрание сочинений: В 6-ти т. Т.3 Проблемы развития психики / Под ред. А.М. Матюшкина. - М. Педагогика, 1983.

9. Каптерев П.Ф. Детская и педагогическая психология. - Москва: Московский психолого-социальный институт, 1999. - 336 с.

10. Кузьминов Я.И. ВШЭ полностью откажется от традиционных лекций в пользу онлайн-курсов [Электронный pecypc] URL: https://rb.ru/news/vshe-study-online

11. Нестик Т. Что делать социологам? Каково место социальных наук в осмыслении цифровизации и искусственного интеллекта? // Социодиггер. 2020. Октябрь. Том 1. Выпуск 3: Цифровизация и искусственный интеллект. - С. 33-37.

12. Петрова Н.П., Бондарева Г.А. Цифровизация и цифровые технологии в образовании // Мир науки, культуры, образования. - 2019. - №5 (78). - С. 353-355.

13. Рудской А.И., Боровков А.И., Романов П.И., Колосова О.В. Пути снижения рисков при построении в России цифровой экономики. Образовательный аспект // высшее образование в России. - 2019. - Т.28. №2. - С. 922.

14. Рыбакина Н.А. Компетентностно-контекстная модель обучения и воспитания в общеобразовательной школе // Образование и наука. - 2017. - Том 19. - № 2. - С. 31-50.

15. Стрекалова Н.Б. Риски внедрения цифровых технологий в образовании // Вестник Самарского университета. История, педагогика, филология. 2019. Т.25. №2. 84-88. DOI: http://doi.org/10.18287/2542-0445-2019-25-284.88.

16. Norton P. Computer Potential and Computer Educators: a Proactive View of Computer Education // Educational Technology - 1983. - Vol. 23. - № 10. - P. 25-28.

\title{
Пашкова А.А., Галашова Е.С. \\ Особенности применения внеурочной деятельности по ОБЖ в средней общеобразовательной школе по данным анкетирования, проведенного на базе школы № 3 города Петрозаводска в 2021 году
}

Петрозаводский государственный университет

(Россия, Петрозаводск)

doi: 10.18411/trnio-12-2021-241

Аннотация

В статье обобщена специфика применения внеурочной деятельности по ОБЖ в средней общеобразовательной школе по данным анкетирования, и приведены рекомендации по внедрению данного вида деятельности в учебный процесс. 
Ключевые слова: внеурочная деятельность, учебный процесс, анкетирование обучающихся, преимущества, специфика.

\section{Abstract}

The article summarizes the specifics of the use of extracurricular activities for life safety in secondary schools according to the survey data, and provides recommendations for the implementation of this type of activity in the educational process. specificity.

Keywords: extracurricular activities, educational process, student survey, advantages,

Внеурочная деятельность является важной частью обучающего процесса, при котором во внеурочное время обучающиеся приобретают ценный социальный опыт общения и коммуникаций, вырабатывают ответственную гражданскую позицию и обучаются принятию самостоятельных решений. Однако часто в современной школе учителя довольно редко в силу своей загруженности на работе применяют ее формы.

Формами внеурочной деятельности могут быть разнообразны:

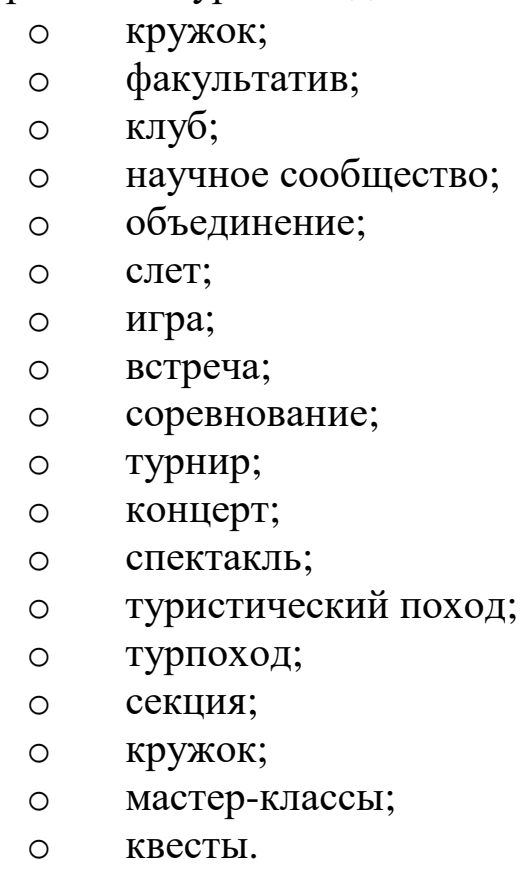

Особенности организации внеурочной деятельности существенно отличаются в каждом учебном заведении и зависят от множества факторов:

- научно-практической ориентации учебного заведения;

- наличия различных возрастных групп;

- привлечения других организаций;

- наличия или отсутствия большого выбора форм проведения внеурочной деятельности;

- опоры на традиции, существующие в конкретном субъекте РФ.

У внеурочной деятельности имеется огромное количество положительных моментов:

- прежде всего, обучающиеся приобретают новые знания, умения и навыки, которые могут быть полезными в профессиональной деятельности;

- развиваются когнитивные способности обучающихся;

- в ходе внеурочной деятельности улучшаются отношения между одноклассниками, формируются новые дружеские связи с детьми из других классов;

- продолжается работа над социализацией детей;

- обучающиеся в игровой форме могут осваивать сложные учебные задачи; 
- д досуг ребенка становится более организованным.

Несмотря на явные преимущества, существуют определенные недостатки, которые скорее относятся не к самой игровой деятельности, а к особенностям ее использования и частоте проведения таких занятий:

— очень часто дети бывают эмоционально перегружены школьной программой, и дополнительные занятия еще более усугубляют их усталость;

- $\quad$ ребенок меньше времени проводит в семье;

- появляется риск дополнительных опасностей, особенно если речь идет о выездных мероприятиях;

- часто отсутствует подготовленный персонал.

Огромной проблемой в проведении внеурочной деятельности является также высокий коэффициент ответственности, который ложиться на учителей в ходе проведения внеурочной деятельности. В российских школах учителя часто сильно загружены проведением и подготовкой основных занятий, работают более, чем на одну ставку и поэтому крайне неохотно идут на проведение дополнительных занятий, которые, как правило, не оплачиваются.

Также большой проблемой является и покупка оборудования, так необходимого при проведении занятий по физике, химии, биологии и географии, а также по ОБЖ.

Целью данной статьи является выявление специфики применения данного вида деятельности в современной школе и отношение к ней обучающихся.

Методикой, которая была использована при написании статьи, стало анкетирование, а базой для проведения анкетирование стали обучающихся 9-11 классов школы № 3 города Петрозаводска.

Главной особенностью внеурочной деятельности является тот факт, что, несмотря на явные преимущества, она практически не проводится школах в рамках курса ОБЖ, как считают $76 \%$ опрошенных. Важно отметить, что сами обучающиеся считают, что внеурочных мероприятий по ОБЖ хотелось бы иметь больше. Так, считают 58\% опрошенных. Главными сложностями при проведении внеурочной деятельности $67 \%$ респондентов называют недостаток практической подготовки и нужной материальной базы, а $12 \%$ заявили о недостатке теоретических знаний. Главными преимуществами применения внеурочной деятельности $36 \%$ респондентов назвали более наглядное усвоение темы занятия, а $41 \%$ заявил, что только на внеурочной деятельности полностью отрабатываются практические действия, связанные с опасными ситуациями на природе.

По рекомендациям обучающихся, в обязательном порядке на природе стоит отрабатывать оказание первой доврачебной помощи, алгоритм спасения утопающего, а также способы выживания в лесу в экстремальных ситуациях.

Как показал опрос, обучающимся в равной степени нравятся различные формы проведения внеурочной деятельности, поэтому при подготовке к данному мероприятию в зависимости от темы занятия учителю нужно будет выбрать подходящую форму для его проведения.

Главной мотивацией при организации внеурочной деятельности на природе 41\% опрошенных считает желание наглядно изучить темы, освоив их на практике, а для 29\% это лишь повод провести время с друзьями на природе ,17\% интерес не испытывают и придут лишь по желанию учителя. Согласно опросу, $45 \%$ респондентов хотели бы, чтобы возможности проведения внеурочной деятельности реализовывались в форме мастерклассов, а 35 \% заявили, что желательной формой внеурочной деятельности были бы квесты.

По итогам исследования были разработаны рекомендации по включению внеурочной деятельности в учебный процесс.

1) Поскольку большинство обучающихся высказалось за то, что им не хватает закрепления теоретических знаний на практике в школьном курсе ОБЖ, то необходимо в обязательном порядке включить внеурочную деятельность в 
форме квестов и мастер-классов по таким разделам дисциплины, как тушение локальных лесных пожаров, выживание в экстремальных условиях в лесу и другие темы, связанные с опасными ситуациями на природе в обязательную школьную программу.

2) Квесты и мастер-классы лучше проводить в осенние, весенние и летние периоды, поскольку погодные условия в данные промежутки года будут наиболее оптимальны для комфортного проведения занятий.

3) В обязательном порядке при проведении внеурочной деятельности на природе учитель обязан её согласовать с руководством школы, а все обучаемые должны иметь прививку от клещевого энцефалита если занятия планируются на местности, которая не обработана от клещей.

4) Желательно чтобы внеурочная деятельность по ОБЖ для более младшего звена школы сопровождалась игровой и развлекательной формой, поскольку это позволит обеспечить и повысить личную заинтересованность обучающихся к данному мероприятию.

5) Перед проведением внеурочной деятельности в рамках курса ОБЖ на природе необходимо провести с обучающимися уроки ознакомления по правилам безопасности и поведения на природе.

6) Кроме этого, перед проведением мероприятия, за день до выезда на природу, необходимо ознакомиться с погодными условиями и после получения нужного результата согласовать или перенести выезд.

7) Перед выездом на природу необходимо рекомендовать обучающимся правильную форму одежды, исходя из погодных условий, а также необходимый инвентарь, который можно взять с собой.

Таким образом, внеурочная деятельность является важной частью учебного процесса, и необходимо согласно ФГОС в обязательном порядке внедрять ее в образовательный процесс и досуг обучающихся.

Как показало анкетирование, современные дети заинтересованы в проведении внеурочной деятельности, и это служит хорошим основанием для проведения подобных мероприятий. Однако, планируя и организуя внеурочную деятельность, необходимо отметить, что надо не допускать эмоциональной и физической перегруженности детей, которые в современном мире помимо школы, как правило, посещают еще несколько кружков и секций.

$$
* * *
$$

1. Архипова О. В. Жизнь после уроков: радость познания// Дополнительное образование и воспитание. - 2013. - № 12. - C. 19-21

2. Ахмерова, Н. М. Педагогика творчества: учебное пособие для вузов / Н. М. Ахмерова, Р. С. Рабаданова, А. Л. Фатыхова. — 2-е изд., испр. и доп. — Москва : Издательство Юрайт, 2021. — 103 с.

3. Бермус, А. Г. Теоретическая педагогика: учебное пособие для вузов / А. Г. Бермус. - 2-е изд. — Москва : Издательство Юрайт, 2021. - 159 с.

4. Бермус, А. Г. Практическая педагогика: учебное пособие для вузов / А. Г. Бермус. - 2-е изд. — Москва: Издательство Юрайт, 2021. - 127 с.

Плащевая Е.В.

Активизация познавательной деятельности у студентов медицинских вузов при изучении медицинской информатики

ФГБОУ ВО «Амурская государственная медицинская академия» (Россия, Благовещенск)

doi: 10.18411/trnio-12-2021-242

\section{Аннотация}

В данной статье рассматриваются формы, пути, приёмы, активизирующие познавательную деятельность у студентов медицинских вузов на занятиях по медицинской 